\title{
Comparison of the Retention of Conventional Dentures after the use of Common Adhesive Brands on Poor Denture Foundations. An in vitro Study
}

\author{
Comparación de la Retención de Dentaduras Convencionales con el uso de Marcas \\ Comerciales de Adhesivos en Procesos Alveolares Deficientes. Un Estudio in vitro
}

\author{
José Zacarías Jaime Flores-León'; Rubén Abraham Domínguez-Pérez²; Héctor Ernesto Ruíz-Valdez'; \\ Carolina Sámano-Valencia ${ }^{3}$; Juan Pablo Loyola-Rodríguez ${ }^{4}$ \& Eduardo Castro-Ruiz ${ }^{1}$
}

FLORES-LEÓN, J. Z. J.; DOMÍNGUEZ-PÉREZ, R. A.; RUÍZ-VALDEZ, H. E.; SÁMANO-VALENCIA, C.; LOYOLARODRÍGUEZ, J. P. \& CASTRO-RUIZ, E. Comparison of the retention of conventional dentures after the use of common adhesive brands on poor denture foundations. An in vitro study. Int. J. Odontostomat., 14(2):236-241, 2020.

ABSTRACT: There is no information about the possible impact in denture retention after the use of common denture adhesives (DAs) when poor denture foundations (PDF) are present. Moreover, there is a lack of information about which current formulation provides greater retention and for how long. Twelve models from edentulous patients with different ridge shape and border height were used and complete dentures were manufactured. Four different formulation brands of DAs were tested after 10 minutes and three, six, nine, and 12 hours of DA application using a universal testing machine. The Fittydent $\Theta$ and Fixodent $\Theta$ adhesives had the highest retention at 12 hours. The PDF group increased on average its retention by $400 \%$. However, the group presented lower retention compared to the good denture foundation group. In conclusion, DAs significantly increased denture retention. The PDF group were the most benefited with the application of DAs. The Fixodent $₫$ paste had the highest retention.

KEY WORDS: denture adhesives, retention, poor denture foundation, good denture foundation.

\section{INTRODUCTION}

It is believed that edentulism rates will remain constant or increase over the next decades (Douglass et al., 2002). Although there are many alternatives to implant treatment for edentulous patients (Doundoulakis et al., 2003), there are still circumstances in which a conventional complete denture is indicated, mainly in developing countries where it remains as the first choice of treatment due to the limited access to complete oral health care services.

The most common complaint of complete denture users is a nonretentive or unstable denture and particle accumulation under it (Siadat et al., 2008). Stability and retention are considered a basic and important requirement for the acceptance of a complete denture by the patient. The denture's performan- ce is determined mainly by the retention [resistance in the movement of a denture away from its tissue foundation especially in a vertical direction (The glossary of prosthodontic terms: ninth edition, 2017)], which greatly depends on denture foundation, which is defined as the oral structure available to support a denture (Koshino et al., 2008).

It is well known that edentulous patients experience continuing resorption of the residual alveolar ridges over the years. The prosthetic replacement of the lost tissues will increase treatment problems causing extreme difficulties in the management of the dentures. Hence, poor denture foundation (PDF) is a serious prosthodontics problem (Atwood, 1971).

\footnotetext{
${ }^{1}$ Clínica de Prostodoncia de la Licenciatura en Odontología, Facultad de Medicina, Universidad Autónoma de Querétaro, México.

${ }^{2}$ Laboratorio Multidisciplinario de Investigación Odontológica, Facultad de Medicina, Universidad Autónoma de Querétaro, México.

${ }^{3}$ Facultad de Estomatología, Benemérita Universidad Autónoma de Puebla, México.

${ }^{4}$ Escuela Superior de Odontología, Universidad Autónoma de Guerrero, México.
} 
FLORES-LEÓN, J. Z. J.; DOMÍNGUEZ-PÉREZ, R. A.; RUÍZ-VALDEZ, H. E.; SÁMANO-VALENCIA, C.; LOYOLA-RODRÍGUEZ, J. P. \& CASTRO-RUIZ, E. Comparison of the retention of conventional dentures after the use of common adhesive brands on poor denture foundations. An in vitro study. Int. J. Odontostomat., 14(2):236-241, 2020.

It has been demonstrated that denture adhesives (DAs) significantly reduce movement (Grasso et al., 1994) and increase retention (Grasso et al.; Munoz et al., 2012). Different subjective [patient-based and quality-of-life outcomes (Kelsey et al., 1997)] and objective [(Kapur index, bite force to measure denture retention, stability and dislodgement (Tarbet et al., 1980) a measure of denture movement in function and masticatory performance (Kapur, 1967), electromyography, and kinesiography (Chew et al., 1985)] methods have been used to demonstrate the effectiveness of DAs.

A great majority of authors have concluded that DAs can provide a softening effect, reduce food particles collecting under the denture, and reduce local pressure points by helping in the distribution of occlusal forces over denture foundation (Tarbet et al.). Additionally, DAs can improve function and increase food chewing force. However, until now, it was not well known if denture retention has benefits and if these equally apply to PDF and good denture foundation (GDF). Moreover, there is a lack of information about which current DA formulation provides greater retention and for how long. Hence, the aim of this study was to evaluate the retention of well-fitting dentures after 10 minutes, and three, six, nine, and 12 hours of the application of some common DAs in two groups of simulated denture foundations (PDF or GDF) under controlled laboratory conditions in vitro.

\section{MATERIAL AND METHOD}

Sixty-three maxillary ridge gypsum models from edentulous patients who received treatment at the Dental School of the Faculty of Medicin at the Universidad Autónoma de Querétaro were examined. Twelve were selected according to their ridge shape and height, two of every kind (Table I). The models were

Table I. Scoring method used to classify denture foundations in two general groups.

\begin{tabular}{llc}
\hline $\begin{array}{l}\text { Ridge Shape } \\
\text { (Score) }\end{array}$ & $\begin{array}{l}\text { Border } \\
\text { height }\end{array}$ & $\begin{array}{c}\text { Total } \\
\text { Score }\end{array}$ \\
\hline Flat (1) & Low (1) & 2 \\
& High (2) & 3 \\
V-Shaped (2) & Low (1) & 3 \\
& High (2) & 4 \\
U-Shaped (3) & Low (1) & 4 \\
& High (2) & 5
\end{tabular}

Good denture foundation (GDF) with a sum score of $\geq 4$ Poor denture foundation (PDF) with a sum score of $\leq 3$. subsequently classified into two groups, GDF group with a sum score $\geq 4$ and a PDF group with a sum of score $\leq 3$.

Every gypsum model was duplicated in acrylic resin (Nic Tone Heat Polymerized, MDC dental, Guadalajara, México) and a complete denture was manufactured following the conventional technique by the same dentist and laboratory technician at the multidisciplinary laboratory of dental research, medical faculty of the Universidad Autónoma de Querétaro, México.

Four different formulation brands of DAs [Corega Ultra ${ }^{\circledR}$, Stafford-Miller (Dungarvan, Ireland); Corega ${ }^{\circledR}$ (Powder), Stafford-Miller (Dungarvan, Irland); Fixodent Original ${ }^{\circledR}$ (Paste), Procter \& Gamble (Gross-Gerau, Germany); Fittydent ${ }^{\circledR}$ (Paste), Fittydent International (Vienna, Austria)] were tested. In order to calculate and standardize the amount of paste and powder adhesive used for each denture, which depended on the denture size and instructions of every DA manufacturer, approximately $1 \mathrm{~cm}$ strips of DAs were applied at the anterior, middle of the hard palate, and right and left middle region of the posterior segments. The strips were then recollected and weighed on an analytical balance and registered. The same amount of paste/powder was applied in each denture in every test.

To perform retention tests in the vertical plane, every complete denture and its respective maxillary ridge acrylic model was attached to a universal testing machine (CMS Metrology). One $\mathrm{ml}$ of synthetic saliva (Panagiotouni et al., 1995) was sprayed inside the denture as well as in the maxillary ridge acrylic model. The corresponding amount of paste or powder was then applied on the denture and it was pressed in place with a $2 \mathrm{~kg}$ brass weight for 15 seconds. An extra 1 $\mathrm{ml}$ of synthetic saliva was sprayed when the powder was applied. All complete dentures and their corresponding adhered maxillary ridge acrylic models were placed in an incubator at $36^{\circ} \mathrm{C}$ and $95 \%$ humidity while the experimental time period was fulfilled in order to simulate intraoral conditions.

Every retention measurement was made with a testing crosshead speed of $1 \mathrm{~mm} /$ minute. The force required to pull the denture apart was measured [Newtons (N)] and recorded. Each DA was tested 3 times in each of the 12 dentures during five time periods: 10 minutes, and three, six, nine, and 12 hours after DA application. Between tests, the dentures and the maxillary ridge acrylic 
models were cleaned with an aqueous solution of detergent under running water and then dried by hand with a paper towel. The denture and acrylic maxillary ridge cleaning was of high importance due to the effects that product residuals might have caused.

All experimental procedures were done at room temperature of $23{ }^{\circ} \mathrm{C} \pm 2{ }^{\circ} \mathrm{C}$ and relative humidity of $50 \% \pm 10 \%$. Retention was expressed in terms of the force necessary to separate the denture from the maxillary ridge acrylic model when a thin film of DA and synthetic saliva was interposed.

Statistical analysis. Quantitative data are expressed as mean, standard deviation, and range. For the determination of variable distribution, a KolmogorovSmirnov test was applied. To detect statistical differences among groups repeated measures ANOVA test was employed and the Tukey's post hoc test. The Student's t-test was applied when comparing the two groups. Statistical significance was set at $p<0.05$ employing GraphPad Prism V3.0 (GraphPad Software, San Diego, CA).

\section{RESULTS}

All tested DAs significantly improved denture retention compared to those with no DA application

Table II. Comparisons of the retention (in newtons) divided by the quality of the denture foundations (Poor Denture Foundation or Good Denture Foundation).

\begin{tabular}{|c|c|c|c|c|c|}
\hline PDF & $\begin{array}{c}\text { Corega Ul tra } \AA \\
\text { Paste }\end{array}$ & $\begin{array}{l}\text { Fittydent }(\mathbb{8}) \\
\text { Paste }\end{array}$ & $\begin{array}{l}\text { Fixodent Original } @ \\
(n=6)\end{array}$ & $\begin{array}{c}\text { Corega } \AA \text { Powder } \\
(n=6)\end{array}$ & $p$-value* \\
\hline 10 minutes & $\begin{array}{c}12.81 \pm 2.33 \\
(9.45-16.20)\end{array}$ & $\begin{array}{l}14.77 \pm 4.86 \\
(8.15-19.90)\end{array}$ & $\begin{array}{c}13.92 \pm 1.93 \\
(12.65-17.70)\end{array}$ & $\begin{array}{c}12.33 \pm 1.90 \\
(9.52-15.32)\end{array}$ & 0.1895 \\
\hline 3 hours & $\begin{array}{l}14.36 \pm 5.04 \\
(9.90-24.10)\end{array}$ & $\begin{array}{l}12.92 \pm 3.87 \\
(8.22-16.96)\end{array}$ & $\begin{array}{c}14.21 \pm 1.38 \\
(12.99-16.70)\end{array}$ & $\begin{array}{c}14.14 \pm 4.82 \\
(10.32-23.54)\end{array}$ & 0.5737 \\
\hline 6 hours & $\begin{array}{r}13.33 \pm 4.73 \\
(8.9-22.35)\end{array}$ & $\begin{array}{c}13.41 \pm 3.35 \\
(9.22-17.03)\end{array}$ & $\begin{array}{c}17.59 \pm 2.12 a \\
(15.44-21.20)\end{array}$ & $\begin{array}{c}14.22 \pm 5.47 \\
(9.33-24.66)\end{array}$ & 0.0378 \\
\hline 9 hours & $\begin{array}{c}15.20 \pm 2.44 \\
(12.55-19.45)\end{array}$ & $\begin{array}{c}16.03 \pm 4.10 b \\
(12.55-21.89)\end{array}$ & $\begin{array}{c}19.73 \pm 2.23 c \\
(17.54-23.41)\end{array}$ & $\begin{array}{c}15.65 \pm 2.82 \\
(12.52-20.21)\end{array}$ & 0.0012 \\
\hline 12 hours & $\begin{array}{c}12.22 \pm 1.80 \\
(10.43-14.95)\end{array}$ & $\begin{array}{c}17.56 \pm 2.99 \\
(15.88-20.55)\end{array}$ & $\begin{array}{l}25.16 \pm 2.10 d, e \\
(22.21-28.43)\end{array}$ & $\begin{array}{c}13.38 \pm 1.35 \\
(11.43-15.00)\end{array}$ & $<0.0001$ \\
\hline$p$-value* & 0.1366 & 0.0007 & $<0.0001$ & 0.1948 & \\
\hline GDF & $\begin{array}{c}\text { Corega Ul tra }{ }^{\circledR} \\
(n=6)\end{array}$ & $\begin{array}{c}\text { Fittydent }{ }^{8} \\
(n=6)\end{array}$ & $\begin{array}{c}\text { Fixodent } \AA \\
(n=6)\end{array}$ & $\begin{array}{c}\text { Corega }{ }^{\circledR} \\
\text { Powder }(n=6)\end{array}$ & p-value* \\
\hline 10 minutes & $\begin{array}{l}23.06 \pm 3.83 \\
(17.43-25.95)\end{array}$ & $\begin{array}{c}23.54 \pm 3.35 \\
(19.21-26.90)\end{array}$ & $\begin{array}{l}21.71 \pm 1.96 \\
(18.50-23.45)\end{array}$ & $\begin{array}{c}20.38 \pm 7.42 \\
(6.49-26.76)\end{array}$ & 0.2716 \\
\hline 3 hours & $\begin{array}{l}23.28 \pm 3.11 \\
(19.28-26.34)\end{array}$ & $\begin{array}{c}19.01 \pm 2.44 f \\
(15.80-22-12)\end{array}$ & $\begin{array}{l}21.48 \pm 2.31 \\
(17.99-23.87)\end{array}$ & $\begin{array}{l}23.34 \pm 2.04 \\
(20.32-25.92)\end{array}$ & 0.0004 \\
\hline 6 hours & $\begin{array}{l}23.12 \pm 3.00 \\
(19.21-25.98)\end{array}$ & $\begin{array}{c}19.24 \pm 2.97 g \\
(14.05-22.03)\end{array}$ & $\begin{array}{l}22.69 \pm 3.00 \\
(19.80-26.98)\end{array}$ & $\begin{array}{l}23.65 \pm 3.40 \\
(18.78-27.88)\end{array}$ & 0.0067 \\
\hline 9 hours & $\begin{array}{r}24.17 \pm 2.32 h \\
(20.54-26.39)\end{array}$ & $\begin{array}{l}24.05 \pm 3.59 \\
(19.32-27.88)\end{array}$ & $\begin{array}{c}30.52 \pm 5.50 i \\
(23.33-38.65)\end{array}$ & $\begin{array}{c}25.87 \pm 2.41 \mathrm{j} \\
(22.98-29.65)\end{array}$ & 0.0149 \\
\hline 12 hours & $\begin{array}{l}20.04 \pm 3.38 \\
(17.50-26.33)\end{array}$ & $\begin{array}{c}25.08 \pm 3.83 \\
(20.53-30.33)\end{array}$ & $\begin{array}{l}36.56 \pm 6.73 k, I \\
(26.33-44.65)\end{array}$ & $\begin{array}{l}21.01 \pm 3.80 \\
(17.90-27.98)\end{array}$ & 0.0016 \\
\hline$p$-value* & 0.0187 & 0.0158 & 0.0004 & 0.1090 & \\
\hline Global PDF & $\begin{array}{c}13.58 \pm 3.46 \\
(8.99-24.10)\end{array}$ & $\begin{array}{l}14.94 \pm 4.00 \\
(8.15-21.89)\end{array}$ & $\begin{array}{r}18.12 \pm 4.58 m \\
(12.65-28.43)\end{array}$ & $\begin{array}{l}13.94 \pm 3.56 \\
(9.33-24.66)\end{array}$ & $<0.0001$ \\
\hline Global GDF & $\begin{array}{l}22.73 \pm 3.27 \\
(17.43-26.39)\end{array}$ & $\begin{array}{c}22.18 \pm 3.99 \\
(14.05-30.33)\end{array}$ & $\begin{array}{l}26.59 \pm 7.30 \\
(17.99-44.65)\end{array}$ & $\begin{array}{l}22.85 \pm 4.44 \\
(6.49-29.65)\end{array}$ & 0.0030 \\
\hline$p$-value ${ }^{\star *}$ & $<0.0001$ & $<0.0001$ & $<0.0001$ & $<0.0001$ & \\
\hline
\end{tabular}

a Fixodent vs Fittydent: $p<0.05$; b Fittydent 9hs vs 6hs: $p<0.05$; c Fixodent vs Corega-Paste, Fittyden, Corega-Powder: $p<0.05$; $d$ Fixodent vs Corega-Paste, Fittyden, Corega-Powder: $p<0.05$; e Fixodent 3hs vs $6 \mathrm{hs}$, 6hs vs 9hs, 9hs vs $12 \mathrm{hs}$ : $p<0.05$; f Fittydent vs Corega-Paste; Fittydent vs Corega-powder: $p<0.05$; g Fittydent vs Fixodent; Fittydent vs Corega-Powder: $p<0.05$; h Corega-Paste 9hs vs Corega-Paste 12hs: $p<0.05$; i Fixodent vs Fittydent: $p<0.05$; j Corega-Powder 9hs vs Corega-powder 12hs: $p<0.05$; k Fixodent vs Corega-Paste, Fittyden, Corega-Powder: $p<0.05$; I Fixodent 12 hs vs Fixodent 9 hs: $p<0.05$; m Fixodent vs Corega-Paste, Fittyden, Corega-Powder: $p<0.05$. ${ }^{*}$ Repeated measures ANOVA and Tukey's post hoc test. ** Student's t-test. 
(baseline). The obtained means of retention from the 12 dentures without DA was $5.38 \pm 3.03 \mathrm{~N}$, whereas, in the study groups $(n=6)$, the GDF's retention was 7.90 $\pm 0.68 \mathrm{~N}$ and for PDF was $2.89 \pm 2.16 \mathrm{~N}$.

Table II shows the comparison of retention on poor or good denture foundations, where GDF showed higher values compared to PDF. The Fixodent ${ }^{\circledR}$ adhesive presented the greatest retention. Both Fittydent $₫$ and Fixodent $₫$ had the highest retention at 12 hours, while the Corega ${ }^{\circledR}$ products (powder and paste) had the highest at 9 hours, but decreased significantly after 12 hours. Table III shows the percentage in which the retention increased in general and divided by groups considering the baseline (retention presented by each of the dentures without DA). In general, the PDF group showed an increase in its retention by $400 \%$ on average while those that were already retentive (GDF group) only increased to a mean of $200 \%$. Although the percentage of retention was much higher in the PDF group, the retention achieved was always lower compared to the GDF group.

Table III. Percentage of increase on retention of every denture adhesive in general and divided by the quality of the foundations considering the baseline (without DA application).

\begin{tabular}{|c|c|c|c|c|}
\hline $\begin{array}{l}\text { Complete } \\
\text { Group }\end{array}$ & $\begin{array}{l}\text { Corega } \\
\text { Ultra® } \\
(n=12)\end{array}$ & $\begin{array}{l}\text { Fittydent } 囚 \\
\quad(n=12)\end{array}$ & $\begin{array}{c}\text { Fixodent } \\
\text { Original }{ }^{\circ} \\
(n=12)\end{array}$ & $\begin{array}{c}\text { Corega }{ }^{\circledR} \\
\text { (Powder) } \\
(n=12)\end{array}$ \\
\hline 10 minutes & $232 \%$ & $254 \%$ & $229 \%$ & $202 \%$ \\
\hline 3 Hours & $248 \%$ & $195 \%$ & $230 \%$ & $247 \%$ \\
\hline 6 Hours & $228 \%$ & $202 \%$ & $273 \%$ & $250 \%$ \\
\hline 9 Hours & $264 \%$ & $271 \%$ & $365 \%$ & $284 \%$ \\
\hline 12 Hours & $198 \%$ & $294 \%$ & $421 \%$ & $218 \%$ \\
\hline Total & $234 \%$ & $243 \%$ & $314 \%$ & $240 \%$ \\
\hline $\begin{array}{l}\text { Poor Denture } \\
\text { Foundation } \\
\text { (PDF) }\end{array}$ & $\begin{array}{c}\text { Corega } \\
\text { Ultra® } \\
(n=6)\end{array}$ & $\begin{array}{l}\text { Fittydent } \AA \\
\quad(n=6)\end{array}$ & $\begin{array}{c}\text { Fixodent } \\
\text { Original }{ }^{\circledR} \\
(n=6)\end{array}$ & $\begin{array}{c}\text { Corega } \mathbb{} \\
\text { (Powder) } \\
(n=6)\end{array}$ \\
\hline 10 minutes & $342 \%$ & $410 \%$ & $381 \%$ & $326 \%$ \\
\hline 3 hours & $396 \%$ & $346 \%$ & $391 \%$ & $388 \%$ \\
\hline 6 hours & $360 \%$ & $363 \%$ & $508 \%$ & $391 \%$ \\
\hline 9 hours & $425 \%$ & $454 \%$ & $581 \%$ & $440 \%$ \\
\hline 12 hours & $322 \%$ & $506 \%$ & $769 \%$ & $362 \%$ \\
\hline Total & $365 \%$ & $416 \%$ & $526 \%$ & $381 \%$ \\
\hline $\begin{array}{l}\text { Good Denture } \\
\text { Foundation } \\
\text { (GDF) }\end{array}$ & $\begin{array}{c}\text { Corega } \\
\text { Ultra® } \\
(n=6)\end{array}$ & $\begin{array}{l}\text { Fittydent }{ }^{\circledR} \\
\quad(n=6)\end{array}$ & $\begin{array}{c}\text { Fixodent } \\
\text { Original }{ }^{\circledR} \\
(n=6)\end{array}$ & $\begin{array}{c}\text { Corega }{ }^{\circledR} \\
\text { (Powder) } \\
(n=6)\end{array}$ \\
\hline 10 minutes & $191 \%$ & $197 \%$ & $174 \%$ & $157 \%$ \\
\hline 3 hours & $194 \%$ & $140 \%$ & $171 \%$ & $195 \%$ \\
\hline 6 hours & $180 \%$ & $143 \%$ & $187 \%$ & $199 \%$ \\
\hline 9 hours & $205 \%$ & $204 \%$ & $286 \%$ & $227 \%$ \\
\hline 12 hours & $153 \%$ & $217 \%$ & $362 \%$ & $165 \%$ \\
\hline Total & $185 \%$ & $180 \%$ & $236 \%$ & $189 \%$ \\
\hline
\end{tabular}

\section{DISCUSSION}

ADA can be an effective aid to denture care. It can improve retention and stability, ensuring adequate function and emotional security. The ideal DA should be nontoxic, nonirritating, odorless, tasteless, and biocompatible with the oral mucosa. Also, DAs should have a neutral $\mathrm{pH}$ as well as to be easy to apply and remove with no potential to cause damage to either denture material or other dental restorative materials (Zhao et al., 2004).
DAs are now recognized as adjuncts to denture treatment, but some decades ago they had a negative outlook, implying they were used to cover inadequacies of denture fabrication (Grasso, 1996). Their application is still discouraged when used as a substitute for good clinical practice (ill-fitting dentures). However, it is a reality that even a well-fitting denture may present problems of retention with PDF. This is a recognized 
FLORES-LEÓN, J. Z. J.; DOMíNGUEZ-PÉREZ, R. A.; RUÍZ-VALDEZ, H. E.; SÁMANO-VALENCIA, C.; LOYOLA-RODRÍGUEZ, J. P. \& CASTRO-RUIZ, E. Comparison of the retention of conventional dentures after the use of common adhesive brands on poor denture foundations. An in vitro study. Int. J. Odontostomat., 14(2):236-241, 2020.

complex problem that affects millions of people around the world due to the continuing reduction of their residual ridges over the years (Atwood).

Several DAs formulations have been on the market in the last decades (Kulak et al., 2005). Their formulas have been modified several times in order to meet the ideal properties, which is mainly to increase stability and retention of dentures so that denture wearers can apply a force increment during mastication, thus needing less chewing strokes to reach deglutition (Kapur; Tarbet et al.).

In the present study, the retention of well-fitting dentures was evaluated in a simulated maxillary ridge acrylic model attached to a universal testing machine using four current $D A s$. The first measurement of retention was made 10 minutes after the DA was applied. This time interval was selected due to unclear instructions of almost every fabricant, which only states: "wait a few minutes before eating". In general, it was found that the measurements performed after 10 minutes and those performed after three hours were very similar. This indicated that indeed, 10 minutes is sufficient for hydration of the material and to achieve retention. Maximum retention was observed at nine hours (Corega $₫$ products) and 12 hours (Fittydent $₫$ and Fixodent $₫$ ). Other studies have reported a peak of retention of dentures with DA at three to five hours suggesting that the reduction in retention could be caused by the loss of DA from the denture due to their solubility in saliva (Swartz et al., 1967; Kanapka, 1984). This could be true since it was not present in this in vitro model.

It has been mentioned that a DA improves denture retention only if the primary properties of the complete denture such as retention, stability, and close adaptation of the denture base to the underlying tissues are acceptable. An ill-fitting complete denture will not become retentive with the mere use of a DA (Panagiotouni et al.); However, it has not been conclusively established whether the use of DAs increases the retention of well-fitting dentures when PDF exists. In this study, it was observed, as expected, that major retention was achieved in complete dentures from the GDF group. On the other hand, the PDF group was the most benefited with a retention increase of up to $700 \%$ (Fixodent $₫$ at 12 hours when analyzing the percentage of retention considering the baseline). Nevertheless, even with this high increase, the PDF group did not achieve the retention as its counterpart, the GDF group. In summary, a well-fitting denture and GDF plus a DA are the best conditions, but a PDF definitely will get benefits with the DA application. This coincides with clinical reports where the effect of a DA on masticatory performance was more significant for denture wearers with PDF than with GDF (Fujimori et al., 2002). The DA application had a positive effect on all performance measures that were more significant for denture wearers with PDF (Munoz et al.).

All current DAs used in this study are similarly formulated on carboxymethylcellulose and their differences are based on the nonbonding synthetic agents, such as polyvinyl acetate, the copolymer of vinyl methyl ether or the maleic anhydride that extend the life of the DA effect, while the carboxymethylcellulose establishes cohesion between the denture and oral mucosa (Torres-Sánchez et al., 2017). Other components have been removed or added, such as zinc. This new product formula could influence previously established properties, including retention. All the DAs used in this study were free of zinc.

DAs should also be designed for easy denture removal, however, none of them are easy to remove from the inner surfaces of the complete dentures, which is consistent with a previous report (Kelsey et al.). It was also observed that compared to DA paste, DA powder is more complicated to apply uniformly, resulting in a thicker layer of DA between the maxillary ridge acrylic model and the complete denture.

Generally, dentists and researchers evaluate DAs using different criteria depending on the patient's individual needs and attitudes, as well as their expectation regarding their complete denture. It is complex to objectively evaluate the benefits of DAs in complete dentures. In this experiment, only retention in the vertical plane was tested, mouth conditions were simulated using artificial saliva, temperature, and humidity. The cruising speed of the universal testing machine was $1 \mathrm{~mm} /$ minute since it has been proved to be the most appropriate testing procedure for bonding test in a similar experiment (Koppang et al., 1995). Our main limitation is that oral mucosa is different in nature and texture from the maxillary ridge acrylic model; it is highly unlikely that DAs perform in the same manner when bonded to keratinized mucosa as they do when bonded to the acrylic resin. Neither mechanical forces nor muscle movements were simulated, which undoubtedly have some effect on DA bond strengths. However, by examining these DAs under the same controlled and constant experimental conditions, it is possible to compare and evaluate their actual retention. It is likely that the same differences 
will also be observed in the oral environment with value variation. In vitro investigations do, however, serve to evaluate and compare currently available and newly formulated DAs in order to validate future clinical trials.

\section{CONCLUSION}

Considering the limitations of this study, it can be concluded that DAs are useful in improving complete denture retention. Among the different DAs tested, Fixodent $\Theta$ paste had the highest retention. The PDFs were the most benefited with the application of DAs, however, even with that high increase, it fails to show the retention shown when using DAs in GDF.

FLORES-LEÓN, J. Z. J.; DOMÍNGUEZ-PÉREZ, R. A.; RUÍZVALDEZ, H. E.; SÁMANO-VALENCIA, C.; LOYOLARODRÍGUEZ, J. P. \& CASTRO-RUIZ, E. Comparación de la retención de dentaduras convencionales con el uso de marcas comerciales de adhesivos en procesos alveolares deficientes. Un estudio in vitro. Int. J. Odontostomat., 14(2):236-241, 2020.

RESUMEN: No existe información acerca del posible impacto en la retención de dentaduras después del uso de adhesivos dentales comunes (DAs) cuando existen rebordes alveolares deficientes (PDF). Más aun, existe una falta de información acerca de cuál formula actual provee mayor retención y por cuanto tiempo. Doce modelos de pacientes edentulos con diferentes formas y alturas en sus rebordes alveolares fueron usados, y dentaduras completas les fueron realizadas. Cuatro diferentes fórmulas y marcas de DAs fueron evaluadas después de 10 minutos, tres, seis, nueve y 12 horas de que se aplicó el DA usando una maquina universal de pruebas. Los adhesivos Fittydent $₫$ y Fixodent $₫$ presentaron la retención más alta a las 12 horas. El grupo con PDF incrementó su retención hasta en un 400 \%. Sin embargo, el grupo presentó menor retención cuando se comparó con el grupo que posee adecuados procesos alveolares. Los DAs incrementaron significativamente la retención de las dentaduras. El grupo PDF fue el más beneficiado con la aplicación de DAs. La pasta Fixodent $₫$ provee la más alta retención.

PALABRAS CLAVE: adhesivos dentales, retención, procesos alveolares deficientes, procesos alveolares adecuados.

\section{REFERENCES}

Atwood, D. A. Reduction of residual ridges: a major oral disease entity. J. Prosthet. Dent., 26(3):266-79, 1971.

Chew, C. L.; Boone, M. E.; Swartz, M. L. \& Phillips, R. W. Denture adhesives: their effects on denture retention and stability. J. Dent., 13(2):152-9, 1985.

Douglass, C. W.; Shih, A. \& Ostry, L. Will there be a need for complete dentures in the United States in 2020? J. Prosthet. Dent., 87(1):5-8, 2002
Doundoulakis, J. H.; Eckert, S. E.; Lindquist, C. C. \& Jeffcoat, M. K. The implant-supported overdenture as an alternative to the complete mandibular denture. J. Am. Dent. Assoc., 134(11):1455-8, 2003.

Fujimori, T.; Hirano, S. \& Hayakawa, I. Effects of a denture adhesive on masticatory functions for complete denture wearers--Consideration for the condition of denture-bearing tissues. J. Med. Dent. Sci., 49(4):1516, 2002.

Grasso, J. E. Denture adhesives: changing attitudes. J. Am. Dent. Assoc., 127(1):90-6, 1996.

Grasso, J. E.; Rendell, J. \& Gay, T. Effect of denture adhesive on the retention and stability of maxillary dentures. J. Prosthet. Dent., 72(4):399-405, 1994.

Kanapka, J. A. Bite force as a measure of denture adhesive efficacy. Compend. Contin. Educ. Dent., Suppl. 4:S26-30, 1984.

Kapur, K. K. A clinical evaluation of denture adhesives. J. Prosthet. Dent., 18(6):550-8, 1967.

Kelsey, C. C.; Lang, B. R. \& Wang, R. F. Examining patients' responses about the effectiveness of five denture adhesive pastes. J. Am. Dent. Assoc., 128(11):1532-8, 1997.

Koppang, R.; Berg, E.; Dahm, S.; Real, C. \& Fløystrand, F. A method for testing denture adhesives. J. Prosthet. Dent., 73(5):486-91, 1995.

Koshino, H.; Hirai, T.; Yokoyama, Y.; Tanaka, M.; Toyoshita, Y.; Iwasaki, K. \& Sudo, E. Mandibular residual ridge shape and the masticatory ability in complete denture wearers. Nihon Hotetsu Shika Gakkai Zasshi, 52(4):488-93, 2008.

Kulak, Y.; Ozcan, M. \& Arikan, A. Subjective assessment by patients of the efficiency of two denture adhesive pastes. J. Prosthodont., 14(4):24852, 2005.

Munoz, C. A.; Gendreau, L.; Shanga, G.; Magnuszewski, T.; Fernandez, P. \& Durocher, J. A clinical study to evaluate denture adhesive use in wellfitting dentures. J. Prosthodont., 21(2):123-9, 2012.

Panagiotouni, E.; Pissiotis, A.; Kaparai, D. \& Kaloyannides, A. Retentive ability of various denture adhesive materials: an in vitro study. J. Prosthet. Dent., 73(6):578-85, 1995.

Siadat, H.; Alikhasi, M.; Mirfazaelian, A.; Geramipanah, F. \& Zaery, F. Patient satisfaction with implant-retained mandibular overdentures: a retrospective study. Clin. Implant. Dent. Relat. Res., 10(2):93-8, 2008.

Swartz, M. L.; Norman, R. D. \& Phillips, R. W. A method for measuring retention of denture adherents: an in vivo study. J. Prosthet. Dent., 17(5):456-63, 1967

Tarbet, W. J.; Boone, M. \& Schmidt, N. F. Effect of a denture adhesive on complete denture dislodgement during mastication. J. Prosthet. Dent., 44(4):374-8, 1980

The glossary of prosthodontic terms: ninth edition. J. Prosthet. Dent. 117(5S):e1-e105, 2017.

Torres-Sánchez, C.; Montoya-Salazar, V.; Torres-Lagares, D.; GutierrezPérez, J. L. \& Jimenez-Castellanos, E. Comparison of masticatory efficacy among complete denture wearers with two adhesives and dentate individuals: a randomized, crossover, double-blind clinical trial. J. Prosthet. Dent., 117(5):614-20, 2017.

Zhao, K.; Cheng, X. R.; Chao, Y. L.; Li, Z. A. \& Han, G. L. Laboratory evaluation of a new denture adhesive. Dent. Mater., 20(5):419-24, 2004.

Corresponding author:

Rubén Abraham Domínguez-Pérez, PhD, MSc, DDS.

Laboratorio Multidisciplinario de Investigación Odontológica

Facultad de Medicina

Universidad Autónoma de Querétaro

Clavel \#200, Prados de La Capilla

C.P. 76176 Santiago de Querétaro, Qro.

MÉXICO

Email: dominguez.ra@uaq.mx

Received: 06-09-2019

Accepted: 08-11-2019 